\title{
Post-Eocene coupled oroclines in the Talesh (NW Iran): paleomagnetic constraints
}

\author{
M. Rezaeian*1 ${ }^{1}$, C.B. Kuijper ${ }^{2}$, A. van der Boon ${ }^{2,3}$, D. Pastor-Gálan ${ }^{2,4,5}$, L.J. Cotton ${ }^{6}$, C.G. \\ Langereis $^{2}$, W. Krijgsman ${ }^{2}$
}

\begin{abstract}
${ }^{1}$ Department of Earth Sciences, Institute for Advanced Studies in the Basic Sciences, Zanjan (Iran), ${ }^{2}$ Paleomagnetic Laboratory Fort Hoofddijk, Utrecht University, Utrecht (The Netherlands), ${ }^{3}$ Geomagnetic Laboratory, University of Liverpool, Liverpool, (United Kingdom), ${ }^{4}$ Center for Northeast Asian Studies, Tohoku University, Sendai (Japan), ${ }^{5}$ Frontier Research Institute for Interdisciplinary Sciences, Tohoku University, Sendai (Japan), ${ }^{6}$ School of Environment, Geography and Geosciences, University of Portsmouth, (United Kingdom).

*corres ponding a uthor
\end{abstract}

\begin{abstract}
The Talesh Mountains (NW Iran) witnessed a long deformation history from the Triassic Cimmerian orogeny to the ongoing Arabia-Eurasia collision. This protracted multi-stage deformation has generated a remarkably curved orogen with a puzzling kinematic and deformational history. In this study, we investigate the origin of the Talesh curvature through paleomagnetic analyses on rocks of Paleozoic, Mesozoic and Cenozoic age. Our results indicate that at least two major, large-scale, vertical-axis-rotations took place since the Late Cretaceous: 1 ) a pre-Eocene $73^{\circ} \pm 17^{\circ}$ clockwise rotation and 2) post-Eocene differential rotations that formed the Z-shaped mountain belt within a crustal-scale shear zone. The latter involved an increasing amount of clockwise (CW) rotation from south $\left(16^{\circ}\right)$ to north $\left(48^{\circ}\right)$. The orocline formation likely started during the Oligocene where an approximately east-west oriented mountain belt was buckled by the Arabia-Eurasia collision, with Arabia acting as a rigid indenter and the South Caspian basin as a rigid backstop. We hypothesise that the NE-SW oriented Aras and Lahijan fault zones, inherited from transform faults related to the Mesozoic opening of the Caspian-Black Sea back-arc, accommodated the coupled orocline formation.
\end{abstract}

Keywords: Paleomagnetism, Arabia-Eurasia collision, Orocline, Aras - Lahijan faults, Tethys, Talesh 


\section{Highlights}

- The Talesh in NW Iran shows a Z shape in map view

- Paleomagnetic analyses support two episodes of vertical axis rotations

- The Talesh rotated $73^{\circ} \pm 17$ clockwise as a rigid block before the Eocene

- After the Eocene, the indentation of Arabia produced the $\mathrm{Z}$ shaped curvature 


\section{Introduction}

Most of the world's mountain belts show a degree of curvature that ranges from changes in strike of a few degrees (like in the Andes; e.g. Maffione et al., 2009), to extreme $180^{\circ}$ turns (as in the Cantabrian Orocline; Pastor-Galán et al., 2015). Curvature in mountain belts may be a primary feature or form during secondary orogenic processes (Carey, 1955; PastorGalán et al., 2017). Orogens with a primary curvature (primary arcs) had an initially curved shape and did not experience any subsequent differential rotation that increased their curvature. In contrast, oroclines (Carey, 1955) were originally straight(er) orogens that acquired part (progressive) or all of their curvature (secondary) during orogenic events (Weil and Sussman, 2004; Johnston et al., 2013). Orocline formation may involve only upper crustal levels or the entire lithosphere (e.g. Johnston et al., 2013) and different formation mechanisms exist. Common examples are subduction roll-back (e.g. Rosenbaum, 2014), indentation of a rigid block (e.g. Meijers et al., 2010), buckling of a continental fragment ( $a$. B. Weil, Gutiérrez-Alonso, Johnston, \& Pastor-Galán, 2013) or a ribbon continent wreck (Johnston, 2001). Understanding orogen curvature kinematics is crucial to unravel the geodynamical mechanisms of orogeny and to make accurate plate reconstructions.

The orogen resulting from the closure of the Tethys oceans is curved from Turkey to Turkmenistan, and includes the Pontides, Lesser Caucasus, Talesh-Alborz and the Kopeh Dagh ranges (Fig. $1 A$ \& B). The Talesh shows a striking " $Z$ " shape in map view that is bounded by major transcurrent crustal-scale faults. These faults are interpreted as paleo-transform fault zones in a continental margin formed during the rifting phase of the South Caspian Basin (SCB) (e.g. Brunet et al., 2003; Abdullayev et al., 2017). All this indicates that the Talesh is decisive in accommodating the Arabia-Eurasia collision.

Previous studies suggest that the Talesh orocline formed from the Oligocene onwards (e.g. Madanipour et al., 2017). However, kinematic data needed for constraining vertical-axis rotations is lacking. The poorly known kinematics of the Talesh hinder the quantification of shortening and prevent paleogeographic reconstructions, which are essential for understanding the evolution of the Arabia-Eurasia collision. Van der Boon et al. (2018) proposed a roughly uniform $\sim 15^{\circ}$ clockwise rotation since the Eocene for all of the Talesh based on paleomagnetic data, but this dataset is limited to the southern part of the Talesh. 
In this paper, we study the whole curvature of the Talesh through paleomagnetic analyses. We sampled seven different localities within the Talesh mountain belt (Asalem, Angula sh, Khanagar, Zeydeh, Karnagh, Khalkhal and Givi localities, Fig. 2) to reconstruct the extent of vertical-axis-rotations and the kinematic evolution of the Talesh.

\subsection{Regional Geological Setting}

Mountain belts in Iran recorded the opening and closing of the Paleo- and Neotethys oceans. The Paleotethys ocean opened during the Paleozoic and started closing along a north-verging subduction zone during the Late Paleozoic to Early Mesozoic (Moghadam et al., 2015). During the start of Paleotethys closure, the northern margin of Gondwana broke, initiating the opening of the Neotethys ocean. A series of microcontinents rifted off the margin (the so-called 'Cimmerian terranes'), which included all Iranian crust north of the Zagros (M. Berberian \& King, 1981).

The Cimmerian terranes migrated northward as the Neotethys ocean opened, while the remnants of the Paleotethys subducted below Eurasia (M. Berberian \& King, 1981; Stampfli \& Borel, 2002). Paleotethys subduction ended when the Cimmerian terranes collided in the Middle to Late Triassic ( $220 \mathrm{Ma}$ ) (Stampfli \& Borel, 2002; Zanchi et al., 2009). Following the Cimmerian orogeny, subduction of Neotethys oceanic crust south of the Cimmerian blocks started in the Late Triassic (M. Berberian \& King, 1981; M.-F. Brunet \& Cloetingh, 2003). During the Jurassic and Cretaceous, a back-arc basin opened in the Caspian Sea and the Black Sea, parallel to the WNW trending Neotethyan subduction zone (Berberian, 1983; Brunet et al., 2003; Agard et al., 2011;). Most recent plate reconstructions support that the opening of the back-arc developed a significant amount of rigid oceanic crust, probably including an incipient ridge-transform system ( e.g. Barrier et al., 2008; Rolland, 2017). From the Late Cretaceous onward, Neotethys oceanic crust obducted over the southern realm, while at its northern margin the northwards subducting slab was exhumed (Agard et al., 2011; Omrani et al., 2013) and the Lesser Caucas us orocline started to bend (Meijers et al., 2015).

Neotethys subduction formed magmatic arcs that today cross Iran from NW to SE (Berberian and Berberian, 1981; Barrier et al., 2008). After the consumption of the Neotethys and its back-arcs and seaways, the Arabian plate collided with Eurasia (Rolland, 2017). The Iranian 
crustal assemblage was shortened during Arabia-Eurasia collision by up to $175 \mathrm{~km}$ (McQuarrie \& van Hinsbergen, 2013; Mouthereau et al., 2012). Reconstruction of the estimated shortening of the Iranian Plateau and the Zagros mountains suggest that collision must have been underway by $20 \mathrm{Ma}$, and may have started around 27-28 Ma (McQuarrie and van Hinsbergen, 2013 and references therein). The Talesh, together with the Alborz and Kopeh Dagh mountains, shows a structural trend that surrounds the SCB (see Fig. 1A \& B)(Allen et al., 2003; Hollingsworth et al., 2010; Cifelli et al., 2015; Mattei et al., 2017). The SCB, bounded in the north by the Apsheron Sill, is one of the world deepest basins, filled with up to $20 \mathrm{~km}$ of sediments (Berberian, 1983; Allen et al., 2002; Brunet et al., 2003). Most of these sediments accumulated from the Oligocene onwards (Abdullayev et al., 2017), coinciding with the exhumation of the surrounding Alborz and Talesh Mountains (Rezaeian et al., 2012; Madanipour et al., 2013). It remains disputed as to whether the origin of the $\mathrm{SCB}$ is thinned continental or unusually thick oceanic crust with remnants of a rift and transform faults (Brunet et al., 2003; Abdullayev et al., 2017).

The Arabia-Eurasia collision is still ongoing. Geophysical evidence shows limited underthrusting of the SCB beneath the continental crust of the Talesh Mountains (e.g. Berberian, 1983; Aziz Zanjani et al., 2013; Bavali et al., 2016). The SCB has acted as a passive indenter that controlled the mechanisms of deformation around it (e.g. Azad et al., 2019). In the western Alborz, sinistral strike-slip faults and a fold-and-thrust system continue to accommodate Arabia-Eurasia convergence, with a total shortening of 15-18 km since the Late Miocene (Guest et al., 2006). The left-lateral strike slip faults have been interpreted as reactivated right-lateral strike-slip faults that accommodated an earlier deformation stage during the Cenozoic (Axen et al., 2001; Mattei et al., 2017). NE-SW transverse basement faults perpendicular to the thrust front are inferred where the western Alborz meets the Talesh (Ehteshami-Moinabadi, 2016). These faults likely reactivated during Arabia-Eurasia collision.

\subsection{Geology of the Talesh}

The Talesh mountain belt in NW Iran extends for approximately $200 \mathrm{~km}$ and contains a geological record that spans from the Ediacaran to the Quaternary (Davies, 1972; Clark et al., 1975). The mountain belt has a "Z" shape in map view (Fig. 1), with a conspicuous N-S oriented middle segment in the predominantly E-W oriented Pontides-Lesser Caucasus- 
Talesh-Alborz-Kopeh Dagh system. The Talesh can be divided into three sectors: (1) the North Talesh, a WNW-ESE oriented segment located mostly in northern Iran and Azerbaijan, which continues to the west in the Lesser Caucasus and Pontides (Fig. 1 A \& B). This segment is a shallow fold-and-thrust belt that accounts for $22 \%$ of shortening during the Cenozoic (ca. 20 km; Madanipour et al. 2013). (2) The Middle Talesh, a NNE-SSW oriented branch, located west of the South Caspian Basin. The Middle Talesh shows less shortening (about $10 \mathrm{~km}$, 15\%) but significant strike-slip deformation (e.g. Allen, 2010; Madanipour et al., 2013). (3) The South Talesh, a NW-SE oriented branch that continues into the Alborz and Kopeh Dagh. The South Talesh is also a fold-and-thrust belt accommodating at least $25 \%$ of Cenozoic shortening ( $25 \mathrm{~km}$; Madanipour et al., 2013).

The Talesh is bound by three major crustal structures: (1) The Aras (or Araks) fault in the north, a sinistral NE-SW trending shear zone that marks the contact between the Talesh and Lesser Caucasus (Jackson and McKenzie, 1983; Devlin et al., 1999; Betancor and Soto, 2015; Zamani and Masson, 2014; Saber et al., 2019) ; (2) The Lahijan fault in the south (Berberian, 1983; Berberian, 1992; Ehteshami-Moinabadi, 2016), a crustal-scale left lateral strike slip fault, which cuts the SCB (Devlin et al., 1999); (3) a N-S dextral fault that is hypothesised along the Caspian coast. Though there are few direct observations of this fault, a large displacement is required to accommodate observed deformation along the western coast of the Caspian Sea (Berberian and King, 1981; Berberian, 1983; Allen et al., 2003). This fault is commonly referred to as the West Caspian fault (Kadirov \& Mammadov, 2008).

The pre-Mesozoic stratigraphic sequence of the Talesh Mountains contains mostly calcareous beds, with some mafic volcanic rocks and clastic sediments (Wendt et al., 2005). Some is olated metamorphic rocks possibly mark the Paleotethys suture in NW Iran (Omrani et al., 2013; Moghadam et al., 2015). In the South Talesh, SW verging thrust faults are considered to be inherited from the Paleotethys subduction zone. Above a Triassic hiatus with a prominent unconformity that marks the Cimmerian orogeny (e.g. Zanchi et al., 2009), the stratigraphic succession continues with up to $3400 \mathrm{~m}$ of Jurassic-Cretaceous rocks, including Early Jurassic polygenic conglomerates topped by clastic rocks and limestone followed by calcareous sandstones (Davies, 1972; Clark et al., 1975). From the Early-Late Cretaceous, the limestone sequence grades into clastic and volcanic rocks. An unconformity separates the Mesozoic from the Cenozoic, which indicates a Late Cretaceous-Early 
Paleogene deformation event (Clark et al., 1975; Berberian and King, 1981; Ziegler and Stampfli, 2001). Apatite fission track ages indicate exhumation of the South Talesh (Madanipour et al., 2013) and Alborz (Rezaeian et al., 2012) during the Late Cretaceous, corroborating a Late Cretaceous-Early Paleogene tectonic event. Several authors interpreted the structural and sedimentological changes as the commencement of shortening related to the Arabia-Eurasia collision at the end of the Cretaceous (Davies, 1972; Clark et al., 1975). The Paleogene in the Alborz and Talesh starts with deposition of the Fajan Formation, which comprises 200 meters of continental conglomerates of Paleocene age. This formation is covered by the Paleocene-middle Eocene nummulitic limestones of the Ziarat Formation $(100-300 \mathrm{~m}$ thick). The top of this formation is of Lutetian age (middle Eocene) in the Alborz (Gravand and Golgir, 2014). After the Lutetian, a flare-up of volcanism led to deposition of the Karaj Formation, which is up to $9 \mathrm{~km}$ thick (Verdel et al., 2011), and has a continental arc geochemical signature (Verdel et al., 2011; van der Boon et al., 2017). Whole-rock ${ }^{40} \mathrm{Ar} /{ }^{39} \mathrm{Ar}$ on the Karaj Formation lava flows shows ages of $\sim 40 \mathrm{Ma}$ (Vincent et al., 2005; van der Boon, 2017). Cenozoic rocks crop out in the Central and Northern Talesh, while older rock units are only locally exposed in the cores of some anticlines (Allen et al., 2003; Vincent et al., 2005; Madanipour et al., 2013). The Karaj Formation is unconformably covered by continental clastic sedimentary sequences of Oligocene and younger ages. This change possibly marks the Cenozoic Arabia-Eurasia continent-continent collision in the Talesh (Vincent et al., 2005; Madanipour et al., 2013).

Together with the Zagros Mountains, the Talesh and Alborz Mountains accommodated most of the shortening related to the Arabia-Eurasia convergence (Mattei et al., 2017). The kinematics of the formation of the Talesh are largely unknown. Structurally, there is a contrast between the tightly folded Mesozoic rocks and the gentle folding of the Cenozoic formations (Clark et al., 1975), which indicates significant pre-Eocene tectonism. Recent studies in the Talesh investigated its exhumation history by thermochronologic analyses together with tectonostratigraphy (e.g. Madanipour et al., 2013; 2017;2018). These studies revealed the ages of three major deformation phases in the Arabia-Eurasia collision recorded in the Talesh: (1) late Oligocene (27-23 Ma); (2) middle Miocene (18-12 Ma); (3) and early Pliocene ( $5 \mathrm{Ma})$. 
However, the origin of the curved geometry of the Talesh remains largely unexplored. Van der Boon et al. (2018) studied four localities in the southern Talesh and found a mostly uniform $\sim 15^{\circ}$ clockwise rotation since the Eocene. There is no available vertical-axis-rotation data from the northern and middle parts of the Talesh. At present, the state of stress in NW Iran, estimated through earthquake focal mechanism solutions (Heidbach, et al., 2016) (see Figure 1) suggests ongoing vertical-axis-rotation. Current seismicity is mainly concentrated on the northern and southern Talesh (Zanjani et al., 2013). This present day seis micity fits the exhumation pattern and the total shortening estimate for the Cenozoic, in which higher rates are observed in the north and south of the Talesh (Madanipour et al., 2013; 2017; 2018).

\section{Materials and methods}

During fieldwork in 2014 and 2015, a total of 408 standard paleomagnetic cores were drilled (2.5 cm diameter) at 58 different sites over 7 different localities (Fig. 2). The Asalem, Angulash, Khanagar and Zeydeh localities contain pre-Cenozoic rocks, and the Givi, Khalkhal and Karnagh localities contain Cenozoic rocks (Fig. 2). Sample and bedding orientations were measured using a magnetic compass, samples of volcanic rocks were additionally oriented using a sun compass. All samples were cut to standard sized specimens ( $22 \mathrm{~mm}$ long) and measured at paleomagnetic laboratory Fort Hoofddijk, Utrecht University. Volcanic rocks were subsequently cut in half because of their strong magnetic signals. All drilling and bedding orientations were corrected for the local declination $\left(5^{\circ}\right)$.

The Asalem locality $\left(37.660^{\circ} \mathrm{N}, 48.823^{\circ} \mathrm{E}\right)$, located $\sim 20 \mathrm{~km}$ to the west of Asalem, consists of 4 sites (T1 to T4) and 45 samples. According to the age constraints in geological maps (e.g. Sahandi and Soheili, 2005) the sites were taken in a folded series of middle to upper Cretaceous limestones, marls and tuffaceous siltstones. At the Angulash locality $\left(37.426^{\circ} \mathrm{N}\right.$, $49.050^{\circ} \mathrm{E}$ ), about $6 \mathrm{~km}$ west of Shanderman, 50 samples were collected over 4 sites, in Jurassic black shales and sandstones (T21) and Cretaceous limestones (T17, T22 and T23). The Khanagar locality $\left(37.293^{\circ} \mathrm{N}, 48.900^{\circ} \mathrm{E}\right)$, ca. $35 \mathrm{~km}$ to the West of Masal, consists of 6 sites (T13-T16, T24 and T32) and 69 samples. Sites T13-T15 and T32 are in Cretaceous limestones with ammonites (Cecca et al., 2012), T24 is part of the Shemshak Formation (lower Jurassic) and T16 and T32 are Paleozoic (likely Devonian) limestones. Finally, the 
Zeydeh locality $\left(37.158^{\circ} \mathrm{N}, 49.000^{\circ} \mathrm{E}\right)$ about $28 \mathrm{~km}$ to the west of Fuman, consists of 4 sites (T25, T27-T28 and T34) and 44 samples. Sites T25, T27 and T34 are lower Cretaceous, and T28 is Jurassic, sampled in the same formations as mentioned for Khanagar.

The Cenozoic Givi locality $\left(37.688^{\circ} \mathrm{N}, 48.391^{\circ} \mathrm{E}\right)$ consists of 16 sites with a total of 97 cores (GV01-GV16) and is located near the town of Givi. It consists mainly of porphyritic basalts, some red beds with baked contacts, and one site in volcaniclastic rocks. The sites were sampled on both limbs of an anticline with a roughly N-S oriented fold axis. The Khalkhal locality $\left(37.604^{\circ} \mathrm{N}, 48.426^{\circ} \mathrm{E}\right)$, some $10 \mathrm{~km}$ west of the city of Khalkhal, includes two series of different lithologies: the KK series contains mainly (porphyritic) basalts, some volcaniclastic rocks and one site with nummulitic limestones, whereas the NL series comprises nummulitic limestones and one basalt. In total, 11 sites were drilled (49 cores) from the KK series and 5 sites (71 cores) from the NL series, along with 2 samples for biostratigraphic analysis. The Karnagh locality $\left(37.264^{\circ} \mathrm{N}, 48.620^{\circ} \mathrm{E}\right)$, includes 7 sites (KA01 - KA07) five of which are volcaniclastic rocks and two are (porphyritic) basalts. In total, 32 cores were sampled from this locality.

\subsection{Foraminiferal biostratigraphy}

We identified larger benthic foraminifera from the limestones of sites NL02 and NL03 to provide biostratigraphic constraints. Individual foraminifera were removed from the surface of the limestones using a mounted needle. The foraminifera were then prepared as equatorially oriented thin sections and measurements of proloculus, consecutive whorl radii and chamber size were taken. Six slides were prepared in total. Taxonomy follows Hottinger (1977) and Schaub (1981).

\subsection{Thermomagnetic analyses}

Thermomagnetic runs of different lithologies were performed on a Curie balance (Mullender et al., 1993), to determine the magnetic carriers in the samples. Samples were powdered using an agate mortar and pestle, and subsequently measured in air in a magnetic field oscillating between 200 and $300 \mathrm{mT}$ under six heating and cooling cycles to increasing temperatures. Successive peak temperatures were $150,300,450,620$, and $700^{\circ} \mathrm{C}$. Heating and cooling rates were $6^{\circ} \mathrm{C}$ and $10{ }^{\circ} \mathrm{C}$ per minute, respectively. 


\section{3 Paleomagnetism}

Thermal demagnetisation was performed in a magnetically shielded furnace to maximum temperatures of $665^{\circ} \mathrm{C}$, using temperature increments of $20-60{ }^{\circ} \mathrm{C}$. Alternating field (AF) demagnetisation was performed up to a maximum of $100 \mathrm{mT}$, with steps of 4-10 mT, using an in-house built robotised system (Mullender et al., 2016). After each demagnetisation step, the magnetisation was measured on a $2 \mathrm{G}$ Enterprise horizontal cryogenic magnetometer equipped with three DC SQUIDS (noise level $3 \times 10^{-12} \mathrm{Am}^{2}$ ). A thermal demagnetisation step of $150{ }^{\circ} \mathrm{C}$ was carried out on limestones before AF demagnetisation to remove possible overprints due to weathering (Van Velzen \& Zijderveld, 1995). Results were calculated using principal component analysis (Kirschvink, 1980) on Zijderveld diagrams (Zijderveld, 1967), using the interpretation portal of the paleomagnetism.org website (Koymans et al., 2016; 2020). Where appropriate, low and high temperature/coercivity components are interpreted separately. For some of the samples, components of magnetisation seem to overlap whereby the resultant directions follow a great-circle demagnetisation path. These directions were interpreted using great circle analysis (McFadden \& McElhinny, 1988). Standard Fisher statistics (Fisher, 1953) are used to determine mean paleomagnetic directions. When possible, we performed bootstrapped fold-tests (Tauxe, 2010; Koymans et al., 2016) to constrain the timing of magnetisation. All fold tests were performed on metre to tens of metres scale folds with horizontal axes.

\subsection{Orocline test}

The orocline test (Pastor-Galán et al., 2017 and references therein) measures the relationship between changes in large structural trends and variations in declinations (or any other structural fabric). The orocline test distinguishes two kinematic end-members: primary arcs and secondary oroclines. In the case of a secondary orocline, there is a one-to-one relation between changes in declination and structural trend, and therefore all the curvature formed after the acquisition of the magnetisation of the rocks from the studied belts. $A$ regression slope close to one indicates a secondary orocline (Schwartz \& Van der Voo, 1983). Slopes between 0 and 1 indicate a progressive orocline (Weil \& Sussman, 2004).

We have estimated the orogenic trend using the orientation of fold axes, which better represent the orogenic trend than bedding strike. When possible, we used our own field measurements (mostly in the case of Mesozoic rocks). In contrast, where strike was difficult 
to measure or subhorizontal (mainly in the Paleogene rocks) we calculated strikes from maps and ortho-photographs. We calculated the strike uncertainty following the procedures described by Yonkee and Weil (2010). Later, we compared the observed strikes with the paleomagnetic declinations and their uncertainties at each locality following the bootstrapped total least squares orocline test (Pastor-Galán et al., 2017).

\section{Results}

\subsection{Biostratigraphy}

All six foraminifera specimens are assigned to Nummulites oblaticus (Supplementary Figure S2). The sectioned specimens from NL02 and NL03 have flattened tests, with no visible external ornamentation. There are approximately 10 chambers in the first whorl, 22 in the second and around 30 in the third. The chambers are very distinctive, being narrow and tall with straight septae, which curve slightly at the periphery. The proloculus in the measured taxa varies between $162 \mu \mathrm{m}$ and $259 \mu \mathrm{m}$, with a mean of $202 \mu \mathrm{m}$, when the measurement is taken perpendicular to the deuteroconch and excluding the chamber wall. The range given for N. oblaticus in Schaub (1981) is slightly smaller; $130-200 \mu \mathrm{m}$, however all other characters are remarkably similar to $N$. oblaticus and the slightly larger proloculus size could be related to regional variation. Nummulites spirotypus is a very similar taxon with a larger proloculus size of $200-350 \mu \mathrm{m}$. However, N. spirotypus has granules on the outside, which were not observed on the sectioned specimens or other individuals on the surface of the limestone sample, making Nummulites oblaticus more likely. Both N. oblaticus and $N$. spirotypus are common in the Tethyan realm of France and Spain (Serra-Kiel et al., 1998). Within larger benthic foraminiferal stratigraphy, N. oblaticus is within Shallow Benthic Zone (SBZ) 7, and N. spirotypus is known from SBZ 7-8 both corresponding to the lower Ypresian (55.8 - 52.8 Ma following Gradstein et al., 2012 and Serra-Kiel et al., 1998).

We have combined structural relationships with the biostratigraphy to give a minimum age estimate for the stratigraphic and volcanic succession. Volcanic dykes of the Karaj Formation cross-cut the nummulitic limestones at the Khalkhal locality (Supplementary Figure S2). The Nummulites from Khalkhal are of lower Ypresian age (55.8 - 52.8 Ma), indicating that the volcanic rocks of the Karaj Formation in the Talesh Mountains are early Eocene or younger. 
$\mathrm{U}-\mathrm{Pb}$ ages on zircons of the volcanic Karaj Formation in the Central Alborz are $49 \mathrm{Ma}$ (base of the Karaj Formation) to $36 \mathrm{Ma}$ (top of the formation, Ballato et al., 2011 and references therein), which are in line with lower (49 Ma) and upper (41 Ma) age estimates of Verdel et al. (2011). Ages of 42.6 - 37.4 Ma in the Tarom area in the western Alborz (Nabatian et al., 2014) show a middle-late Eocene age of the volcanic and volcaniclastic rocks of the Karaj Formation in this region. Age estimates for pre-Eocene rocks are biostratigraphic ages from maps (Davies, 1972; Clark et al., 1975).

\subsection{Thermomagnetic runs}

The thermomagnetic curves of basalts and volcaniclastic rocks generally show a gradual decrease in magnetisation upon heating until $580^{\circ} \mathrm{C}$ (Fig. 3a, b, c), which indicates the presence of magnetite. Some samples (e.g. KA02) have Curie temperatures of $560{ }^{\circ} \mathrm{C}$ (Fig. 3c) indicating the presence of some titanomagnetite with a lower Curie temperature than Tipoor magnetite (Tauxe, 2010). In other samples, higher Curie temperatures are observed, which are most likely related to the presence of maghemite (Curie temperature of $645^{\circ} \mathrm{C}$ ). The magnetic signal of limestones is much weaker compared to the volcanic rocks. Limestones show reversible behaviour until an increase in magnetisation is observed around $420{ }^{\circ} \mathrm{C}$, indicating the oxidation of iron sulphides, most likely pyrite (Fig. 3d). Red beds (GV10.11) and baked contacts (GV10.08) show a constant reversible decrease in magnetisation until $550{ }^{\circ} \mathrm{C}$ where a rapid decrease in magnetisation takes place until $680^{\circ} \mathrm{C}$, indicating the presence of hematite (see Fig. 3e, f).

\subsection{Paleomagnetism}

Overall, the basalts, volcaniclastic rocks and red beds give more consistent directions than the limestones (Fig. 4, 5 \& 6; Table S1; Supplementary Figures S3-S9). NRM intensities of basalts and volcaniclastic rocks are relatively high, mostly between $150 \mathrm{~mA} / \mathrm{m}$ and $2 \mathrm{~A} / \mathrm{m}$, while intensities of the limestones are much lower, with a maximum of $3 \mathrm{~mA} / \mathrm{m}$. In the sites consisting of lava flows, we used only those with a dispersion parameter k>50 (Bigginet al., 2008). All directions obtained from a single lava flow (single site) were averaged to one site direction. Subsequently, we calculated the mean of at least seven sites (>7 lava flows) per locality, to average out paleosecular variation. For sedimentary rocks, we averaged all available individual results from each site. Results of all measurements are given in Tables S1 and S2, and the following paragraphs give a detailed description of each locality. 


\subsubsection{Asalem (T1-T4)}

All samples from the Asalem locality show stable components that decay towards the origin (Supplementary Figure S7). Many samples display viscous components up to $240{ }^{\circ} \mathrm{C} / 20 \mathrm{mT}$. All samples show normal polarity and directions are well-grouped in T1, T3 and T4 and less in T2 (Table S1). The average ChRM directions of each site cluster better after tectonic correction, with the exception of T1. Maximum clustering is achieved if we consider T1 as remagnetised after folding but previous to any vertical-axis-rotation. Using that assumption, the statistical parameters are $\mathrm{Dec}=119.1^{\circ}, \mathrm{Inc}=44.1^{\circ}, \mathrm{K}=16.0$ and $\mathrm{A} 95=5.5$ (before tilt correction; NOTC) and $\mathrm{Dec}=136.6^{\circ}, \mathrm{Inc}=43.8^{\circ}, \mathrm{K}=29.6$ and $\mathrm{A} 95=4$ (after tilt correction; TC) (Fig. 6). The sites of this locality pass a fold-test (Fig. 7).

\subsubsection{Angulash (T17, T21-T23)}

Only sites T22 and T23 of the Angulash locality provided interpretable results. Site T17 is a very weakly magnetised limestone that did not yield an interpretable ChRM. In contrast, T21 (Jurassic), shows a ChRM consistent with the present-day-field and was excluded from further analyses. T22 and T23 have single components that decay towards the origin (Fig. 6). Some of the samples display a viscous component up to $150{ }^{\circ} \mathrm{C} / 12 \mathrm{mT}$ (Supplementary Figure S7). The ChRM of both sites together show a better clustering and positive fold-test after tilt correction. The statistical parameters are: $\mathrm{Dec}=145.2^{\circ}, \mathrm{Inc}=83.9^{\circ}, \mathrm{K}=9.6$ and $\mathrm{A} 95$ $=10.8$ (NOTC); and Dec $=72^{\circ}, \mathrm{Inc}=51.4^{\circ}, \mathrm{K}=29.8$ and $\mathrm{A} 95=5.4$ (TC) (Table S1).

\subsubsection{Khanagar (T13-T16, T24 and T32)}

At the Khanagar locality, we used the results of sites T13-T16 and T32. T14 shows two polarities whereas T13, T15, T16 and T32 show a single (normal) one. Although individual cores of T24 (Jurassic) are interpretable, the distribution of individual directions shows a random distribution, and this site was excluded for further analyses. Most of the individual samples in this locality show a viscous component up to $150-200^{\circ} \mathrm{C}$ or $12-20 \mathrm{mT}$, and a ChRM that commonly demagnetises towards the origin (Supplementary Figure S7). Paleozoic sites T16 and T32 do not pass a fold test, implying a remagnetisation of these samples. Samples from sites T13-T15 cluster significantly better after tilt correction and pass a fold test (Fig. 7). Mesozoic rocks unconformably overlie the Paleozoic rocks (Clark et al., 1975). Paleozoic sites T16 and T32 show directions in geographic coordinates (NOTC) that fit well with the tilt corrected (TC) directions of T13-T15. This suggests a remagnetisation of the Paleozoic rocks. 
We added T16 and T32 (NOTC) to the Khanagar locality (Fig. 6). The average directions from Khanagar locality are then: $\operatorname{Dec}=91.6^{\circ}, \mathrm{Inc}=35.9^{\circ}, \mathrm{K}=12.2$ and $\mathrm{A} 95=6.6$ (NOTC); and Dec = $104^{\circ}, \operatorname{Inc}=56.9^{\circ}, \mathrm{K}=13.5$ and $\mathrm{A} 95=5.9$ (TC) (Table S1 and Fig. 6).

\subsubsection{Zeydeh (T25, T27, T28 and T34)}

Some samples of the Zeydeh locality show a viscous component that is usually removed at $150^{\circ} \mathrm{C} / 12 \mathrm{mT}$, and a ChRM that mostly demagnetises to the origin. The directions from sites T25 and T34 scatter over $90^{\circ}$ (both before and after tilt corrections). Directions from sites T27 and T28 cluster slightly better after tilt and the inclinations are more reasonable. The average directions are: $\mathrm{Dec}=71.7^{\circ}, \mathrm{Inc}=61.1^{\circ}, \mathrm{K}=17.1, \mathrm{~A} 95=8.9(\mathrm{NOTC})$, and $\mathrm{Dec}=27.6^{\circ}$, Inc $=49.5^{\circ}, \mathrm{K}=18.0, \mathrm{~A} 95=9.6(\mathrm{TC})$.

\subsubsection{Givi (GV series)}

All samples from the Givi locality show reversed polarity (see Supplementary Figure 3). Results of red beds and baked contacts cluster at temperatures up to $450{ }^{\circ} \mathrm{C}$ and decay towards the origin afterwards (Supplementary Figure S3). Some basaltic samples show a (viscous) low temperature component up to $150 / 200^{\circ} \mathrm{C}$. After $200^{\circ} \mathrm{C}$, the samples demagnetise towards the origin (Supplementary Figure S3). GV02 ( $\alpha 95=41.3$ and $k=10.0$ ) is excluded due to its low $k$ value. Other sites show $k$ values between 74.9 and 612.4 for basalts, and $k$ values of 41.7 and 169.1 for red beds (GV10 and GV15). The mean ChRM directions of the 16 sites before and after tectonic corrections (normalised) are almost identical. Average directions are $\mathrm{Dec}=59.4^{\circ}, \mathrm{Inc}=46.5^{\circ}, \mathrm{K}=17.4$ and $\mathrm{A} 95=9.4$ (NOTC), and $\operatorname{Dec}=58.8^{\circ}, \operatorname{lnc}=50.5^{\circ}, \mathrm{K}=14.8$ and A95 $=9.9$ (TC) (Fig. 4; Table S1). Site GV13 is rejected after applying a classical $45^{\circ}$ cut-off (Koymans et al., 2016 and references therein). The fold test for all GV sites gives an optimal clustering between 30 and 119\% unfolding (see Fig. 7), marginally positive.

\subsubsection{Khalkhal (KK and NL series)}

The Khalkhal locality consists of 10 volcanic sites and 5 nummulitic limestone sites (see supplementary Figure S4). Some samples show a low temperature/low coercivity (LT/LC) component up to $450{ }^{\circ} \mathrm{C} / 20 \mathrm{mT}$. KK and NL series were interpreted and grouped separately (Fig. 4 and 5). Only 5 sites gave $\mathrm{k}>50$ (Table S1), with an average of: $\mathrm{Dec}=41.6^{\circ}, \mathrm{Inc}=51.6^{\circ}, \mathrm{K}$ $=13.8$ and $\mathrm{A} 95=21.3($ NOTC $)$, and $\mathrm{Dec}=21.4^{\circ}, \mathrm{Inc}=53.2^{\circ}, \mathrm{K}=13.5$ and $\mathrm{A} 95=21.6$ (TC). 
Nummulitic limestones of the Khalkhal locality were treated independently. NL01 and NL02 show almost only LT/LC components (up to $175^{\circ} \mathrm{C} / 25 \mathrm{mT}$ ) and become scattered at higher temperatures/coercivities. Intensities of NL03 are relatively high compared to the other NL sites $(1300 \mu \mathrm{A} / \mathrm{m}$ for NL03 vs. $300 \mu \mathrm{A} / \mathrm{m}$ for NL01 and NL02). Taking all the NL sites together, the ChRM directions are slightly better clustered before tilt correction with $\mathrm{Dec}=49.4^{\circ}, \mathrm{InC}=$ $36.4^{\circ}, \mathrm{K}=18.0$ and $\mathrm{A} 95=6.0$ (Fig. 5 and Supplementary Figure S5). After tilt correction, the average is: $\mathrm{Dec}=57.6^{\circ}, \mathrm{Inc}=44.6^{\circ}, \mathrm{K}=13.5$ and $\mathrm{A} 95=7.1$ (Table S1).

Mean declinations of both the KK and NL series correspond well in geographic coordinates: $41.6^{\circ} \pm 25.5$ and $49.4^{\circ} \pm 6.4$, respectively. This, together with a negative fold test of KK and NL (see Fig. 7d) and a positive common true mean direction (CTMD) test of KK and NL in geographic coordinates (Fig 7e), indicates that the nummulitic limestones were tilted before the extrusion of KK volcanic rocks and were likely remagnetised by the volcanic rocks.

\subsubsection{Karnagh (KA series)}

The Karnagh locality consists of 7 sites (Fig. 4; Supplementary Figure S6). In most cases there is a single component that decays towards the origin. Some samples display a low temperature component up to $300^{\circ} \mathrm{C} / 20 \mathrm{mT}$, and a high temperature/high coercivity component that decays towards the origin. All samples show normal directions and all sites are well-grouped, with $\mathrm{k}>50$ (Table S1). Mean directions are $\mathrm{Dec}=25.6^{\circ}, \operatorname{Inc}=59.0^{\circ}, \mathrm{K}=18.1$ and $A 95=16.1$ (NOTC) (Fig. 4 and Supplementary Figure S6), and Dec $=34.1^{\circ}, \operatorname{lnc}=44.1^{\circ}, \mathrm{K}=$ 18.1 and $\mathrm{A} 95=14.6$ (TC) (Table S1).

\subsection{Orocline test}

We performed a bootstrapped total least squares orocline test (Pastor-Galán et al., 2017) (see Fig. 8) on the Eocene and pre-Eocene data. We combined our new data on the Eocene with the data from van der Boon et al. (2018). To compare the results from both orocline tests we normalised the structural trend to a common reference strike $\left(S_{0}\right)$ of $139^{\circ}$ and declinations to the reference declination $\left(D_{0}\right)$ of Eurasia of ca. $10^{\circ}$ (Torsvik et al., 2012). The slope of the orocline test is $m_{1}=0.9 \pm 0.3$ (Eocene) and $m_{2}=1.1 \pm 0.2$ (Pre-Eocene) (Fig. 8), indicating that both are secondary oroclines. Confidence intervals are large due to the small number of localities considered (7 Eocene and 4 pre-Eocene; Fig. 8). Both slopes show a very high correlation coefficient (Pearsons $\rho=0.92$ for the Eocene and 0.99 for pre-Eocene). 
Remarkably, the intercepts (where the regression line cuts the vertical axis) are very different, $17^{\circ} \pm 10.8$ (Eocene) and $90^{\circ} \pm 7.2$ (pre-Eocene). Strikes and declinations were normalized to the same reference strike $\left(S_{0}\right)$ and same reference declination $\left(D_{0}\right)$. Therefore, the difference in intercept represents a rigid vertical-axis-rotation that happened between deposition of Cretaceous rocks, which show W and SW declinations further to the west, and the extrusion of Eocene volcanics (NW declinations).

\section{Discussion}

\subsection{Kinematics of vertical-axis-rotations}

The studied localities, together with data of van der Boon et al. (2018), are located in the Middle and South Talesh. All sites show various degrees of clockwise rotations (Fig. 9) with respect to Eurasia (ca. $10^{\circ}$ for the entire Cretaceous-Eocene period following Torsvik et al., 2012). Van der Boon et al. (2018) hypothesized a uniform rotation of about $\sim 15^{\circ}$ clockwise for the whole Talesh; however, our results suggest a more complicated kinematic history. The Middle Talesh shows larger clockwise rotations than the rest of the Talesh. Furthermore, pre-Eocene rocks show significantly higher clockwise rotations (Fig. 9), suggesting a preEocene rotational event.

The declination of the Karnagh locality $\left(34.1^{\circ} \pm 16.2\right)$, located in the South Talesh, between the Kajal and Meshkin localities from van der Boon et al. (2018), is statistically indistinguishable from the Kajal and Meshkin localities (e.g. Fig. 7e) and similar to their Zanjan and Zaaker localities (Fig. 9). Altogether, South Talesh localities have experienced roughly the same $10^{\circ}$ to $20^{\circ} \mathrm{CW}$ rotation since the middle to late Eocene. The Khalkhal (KK) locality lies in the hinge between the South and Middle Talesh, and its declination $\left(48.6^{\circ} \pm\right.$ 6.2 ) indicates a clockwise rotation of approximately $39^{\circ}$ since the middle-late Eocene (corrected for the expected declination of $10^{\circ}$ from Torsvik et al., 2012). Finally, the Givi (GV) locality (Middle Talesh), shows a declination of $58.8^{\circ} \pm 11.6$, indicating a rotation of approximately $49^{\circ}$ since the middle -late Eocene.

We recognise a similar pattern with larger rotations in the Middle Talesh compared to the South Talesh in the pre-Eocene localities, although all of them recorded a higher degree of clockwise rotation (Fig. 9). The Zeydeh locality is located in the South Talesh, where its strike 
is E-W trending (Fig. 2 ) and its declination (27.6 \pm 11 ) implies roughly $17^{\circ}$ of clockwise rotation (obtained declination minus expected declination of $10^{\circ}$ ). The rotations increase where the structural trend becomes progressively more N-S (Fig. 9): Angulash with a rotation of $62^{\circ} \mathrm{CW}\left(\mathrm{Dec}=72^{\circ} \pm 6\right)$; Khanagar with a rotation of $99^{\circ} \mathrm{CW}\left(\mathrm{Dec}=109^{\circ} \pm 7.1\right)$; and Asalem $127^{\circ}\left(\mathrm{Dec}=136 \cdot 6^{\circ} \pm 4.4\right)$. Since the structural trend is comparable to the Eocene localities, we conclude that there is a significant amount of vertical-axis-rotation that happened between the deposition of the youngest Cretaceous rocks studied and the Eocene volcanic activity.

Our orocline tests, with slopes of 0.9 (Eocene) and 1.1 (Pre-Eocene), indicate that the " $Z$ " curvature of the Talesh is a secondary orocline. Although confidence intervals are la rge (0.6 - 1.2 for Eocene and $0.9-1.3$ for pre-Eocene), a primary origin of curvature is excluded (Fig. 8). We have normalised the strike and declination for both orocline tests to compare them. Despite the coincidence in slope and confidence interval, there is a large difference in the intercept, $73^{\circ} \pm 17$ (Fig. 8). This implies that the pre-Eocene sites were rotated as a rigid block, without accompanying oroclinal bending. Hence, oroclinal bending of both preEocene and Eocene rocks must have happened after the Eocene.

\subsection{Pre-Eocene rotation}

All pre-Eocene localities come from a relatively small area (Fig. 2), and thus the size of the rotated block is unknown. The cause of the observed pre-Eocene rotation could be either local or regional, which hampers the integration into a regional plate reconstruction. A preEocene rotation in the Talesh is coherent with the rotation pattern observed in the Lesser Caucasus, where Meijers et al. (2015) found two rotational events. They suggested a preEocene rotation, which they linked to the Cretaceous collision between the South Armenian block and Eurasia, and a post-Eocene rotation related to the Arabia-Eurasia collision.

The Mesozoic of the Talesh is more deformed than the Cenozoic, and apatite fission track ages support exhumation during the Late Cretaceous in the South Talesh (Madanipour et al., 2013). We therefore suggest that the rotation of pre-Eocene units is linked to a Late Cretaceous deformation event, as this is the only reported major tectonic event (Agard et al., 2011; Meijers et al., 2015). 


\subsection{Coupled Orocline bending in the Talesh}

The Talesh "Z" shape surrounds the SCB together with Alborz and Kopeh Dagh (Fig. 1A \& B). At present, the state of stress in the study area, estimated through earthquake focal mechanism solutions (Heidbach et al., 2016) shows a deviation from the general trend which is attributed to the SCB acting as an indenter (Fig. 1A). In the Talesh, the maximum horizontal stress trends - from south to north: E-W, NW-SE and NE-SW - follow a fan shaped pattern that continues along the southern-central part of SCB-Talesh boundary (Fig.1A).

Our new results show differential rotation in the Talesh, with $16^{\circ}$ of $\mathrm{CW}$ rotation in the South Talesh, to $48^{\circ} \mathrm{CW}$ in the Middle Talesh. Considering the data from adjacent areas to the east and north of the Talesh (Cowgill et al., 2016; Hollingsworth et al., 2010; Mattei et al., 2017; Meijers et al., 2015); we conclude that the Talesh was part of an Eocene mountain belt that was roughly $\mathrm{E}-\mathrm{W}$ oriented before oroclinal bending.

These results support a model in which initial Arabia-Eurasia collision caused a $\sim 20^{\circ}$ rotation in the Talesh (van der Boon et al., 2018) which rotated together with the Lesser Caucasus and Eastern Pontides (Meijers et al., 2015; van der Boon et al., 2018). Once the oceanic basin south of the Caucasus was consumed (Cowgill et al., 2016; van der Boon et al., 2018), convergence was accommodated by continental deformation and vertical-axis-rotations. Since the rotation is controlled by the generally rigid SCB, the continued convergence forced the Talesh into three segments (North, Middle and South) with a Z-shape. Our kinematic constraints fit with the deformation patterns of the Talesh: shortening in the North and South Talesh, where rotations are of lesser magnitude; and significant strike-slip movement in the Middle Talesh. In addition, our vertical-axis rotations are in agreement with the exhumation events revealed by bedrock cooling ages (e.g. Madanipour et al., 2017).

As a preliminary hypothesis, we suggest that most of the deformation that produced the clockwise rotations could be accommodated by a rejuvenation of ridge-transform faults in the Cretaceous, which today are the Lahijan and Aras faults (see sketch in Figure 10) (e.g. Berberian, 1983; Jackson and McKenzie, 1983). Based on our scenario presented in Figure 10, post-Eocene oroclinal bending of the Talesh Mountains provides a mechanism to accommodate more Arabia-Eurasia convergence than previously thought, facilitating further plate reconstructions (Cowgill et al., 2016; van der Boon et al., 2018). 


\section{Conclusions}

The Talesh Mountains in northwest Iran show clockwise vertical-axis-rotations in both Mesozoic and Paleogene rocks. The performed orocline tests in Eocene and pre-Eocene rocks support that all changes in strike in the Talesh are due to vertical-axis-rotations, and the Talesh Mountains form a post-Eocene secondary orocline. The Talesh Mountains were originally a roughly straight terrane during the Eocene, which was bent after the Eocene into its present day " $Z$ " shape. In addition, our research shows that the pre-Eocene rocks rotated some $73^{\circ} \pm 17$ clockwise as a rigid block before the Eocene. We attribute this pre-Eocene rotation to a major Late Cretaceous deformation event (e.g. Meijers et al., 2015).

Indentation of Arabia into Eurasia drove the formation of oroclines from the Pontides to the Kopeh Dagh, of which the Talesh is a significant part. Ongoing shortening due to the ArabiaEurasia convergence and the immobility of the rigid South Caspian Basin forced double bending ( $Z$ shape) of the Talesh, possibly enabled by the reactivation of the Aras and Lahijan faults.

\section{Acknowledgments}

We thank Ali Niknam and Abdolreza Ghods for field assistance. This work was financially supported by the Netherlands Organization for Scientific Research (NWO) [grant 865.10.011] of WK. DPG is funded by a post-doctoral fellowship from The Netherlands Research Centre for Integrated Solid Earth Sciences (ISES) and a fellowship for overseas researchers from the Japan Society for Promotion of Science (JSPS) (grant P16329) and a MEXT/JSPS KAKENHI Grant (JP16F16329). 


\section{Figures}
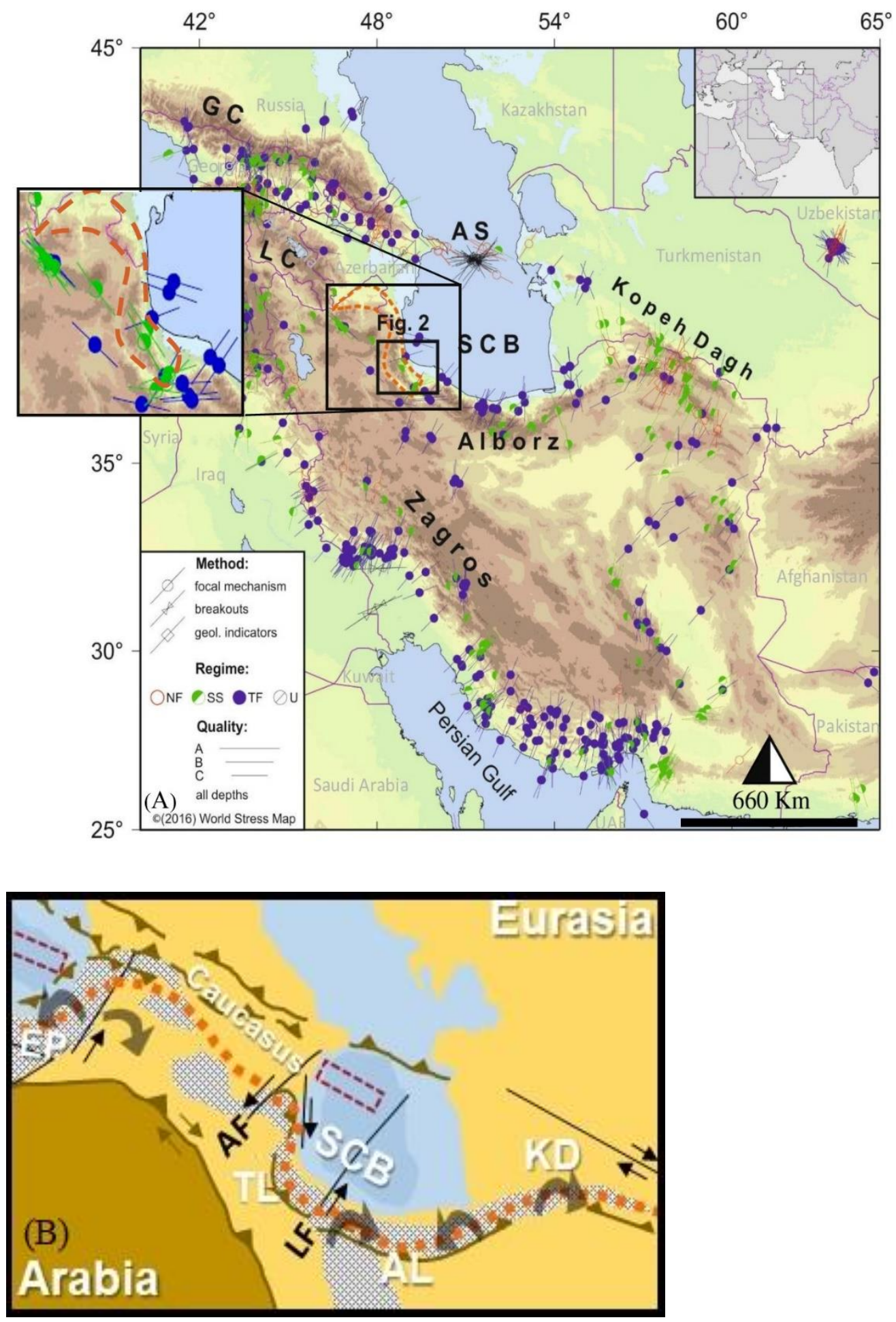

Fig. 1: (A) Present day stress map of the Caucasus, Caspian Sea, Alborz, Zagros and Kopeh Dagh area. A simplified elevation map of Iran overlaid by the data extracted from the WSM database release 2016 (doi:10.5880/WSM.2016.001) showing the upper $40 \mathrm{~km}$ crustal present-day stress field (Heidbach et al., 2016). Colours indicate stress regimes with red for 
normal faulting (NF), green for strike-slip faulting (SS), blue for thrust faulting (TF), and black for unknown (U). In the study area, strike slip and thrust stress regimes are dominant. Orange stippled line represents the outlines of the Talesh Mountains. Black boxes are the location map for Fig. 2 and magnified Z-shaped Talesh including current maximum horizontal stress. AS, SCB, GC and LC are abbreviations for Apsheron Sill, South Caspian Sea, Greater Caucasus, and Lesser Caucasus, respectively. In the study area, two groups of maximum horizontal stresses are pronounced: a major orogen-parallel stress regime and a minor orogen-perpendicular stress regime.

(B) Tectonic map between the South Caspian and Black Sea region in the collision zone between Arabia and Eurasia. AF, Aras Fault; AL, Alborz; EP, Eastern Pontides; KD, Kopeh Dagh; LF, Lahijan Fault; SCB, South Caspian Basin; TL, Talesh. Broken orange line corresponds to the trend of the Eastern Pontides, Caucasus, Talesh, Alborz and Kopeh Dagh fold - thrust belts. Black arrows indicate the sense of rotation in both limbs of the oroclines (modified after Meijers et al. (2015) and Mattei et al. (2019)). Blue dark shadow indicates the probable oceanic crust and former rift center in SCB and Black sea. Relevant paleo-rift centers are shown by dashed lined rectangles (Abdullayev et al., 2017; Shillington et al., 2009). 


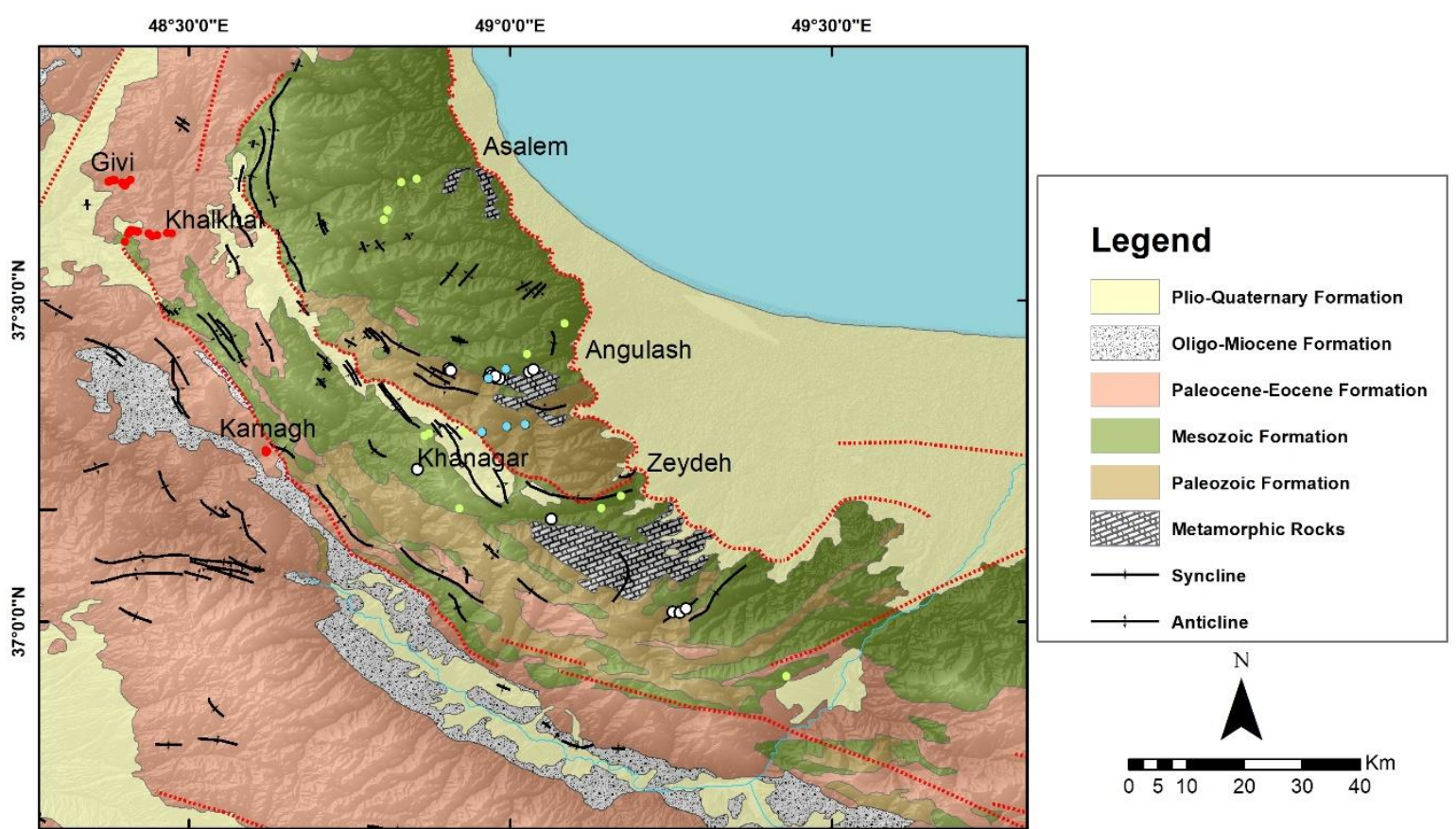

Fig. 2: Geological map of the study area based on the 1:250,000 compiled geological maps of Iran (Sahandi and Soheili, 2005). Red stippled lines are the main faults, based on Hessami and Jamali (2006), Berberian and Walker (2010), Zanjani et al. (2013), Faridi et al. (2017). Black lines correspond with anticline and syncline fold axes, extracted from 1:100,000 geological maps of Kivi, Khalkhal, Hashtjin, Masuleh, Bandar Anzali and Rudbar. Three groups of samples are indicated: red circles are Eocene, green circles are Cretaceous, and blue circles are pre-Cretaceous sample locations. The white circles represent sample locations that did not yield results. 

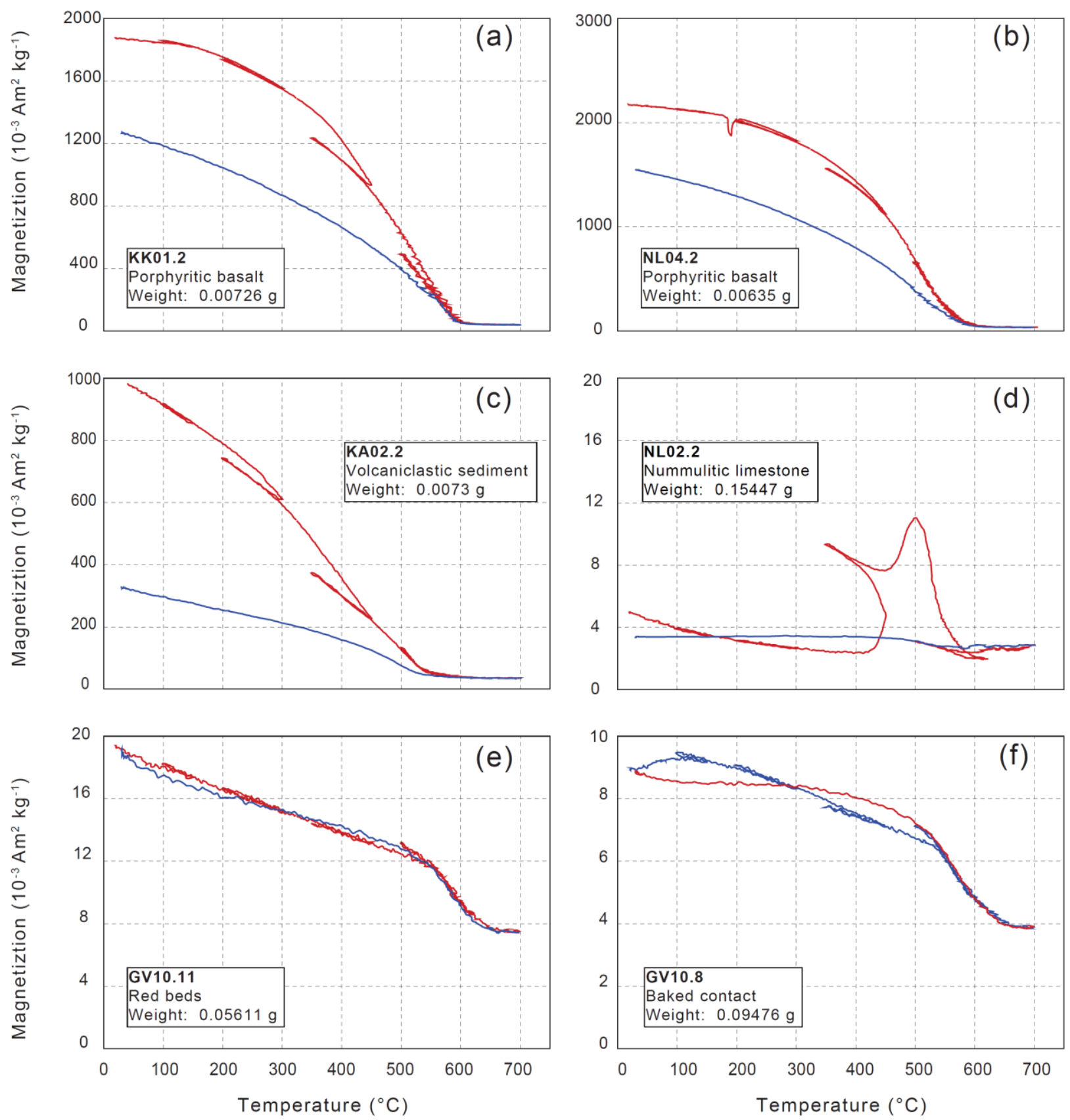

Fig. 3: Example of thermomagnetic runs using a Curie balance (T. A. T. Mullender et al., 1993). Red curves indicate heating and cooling cycles, blue curves indicate the final cooling curve. 


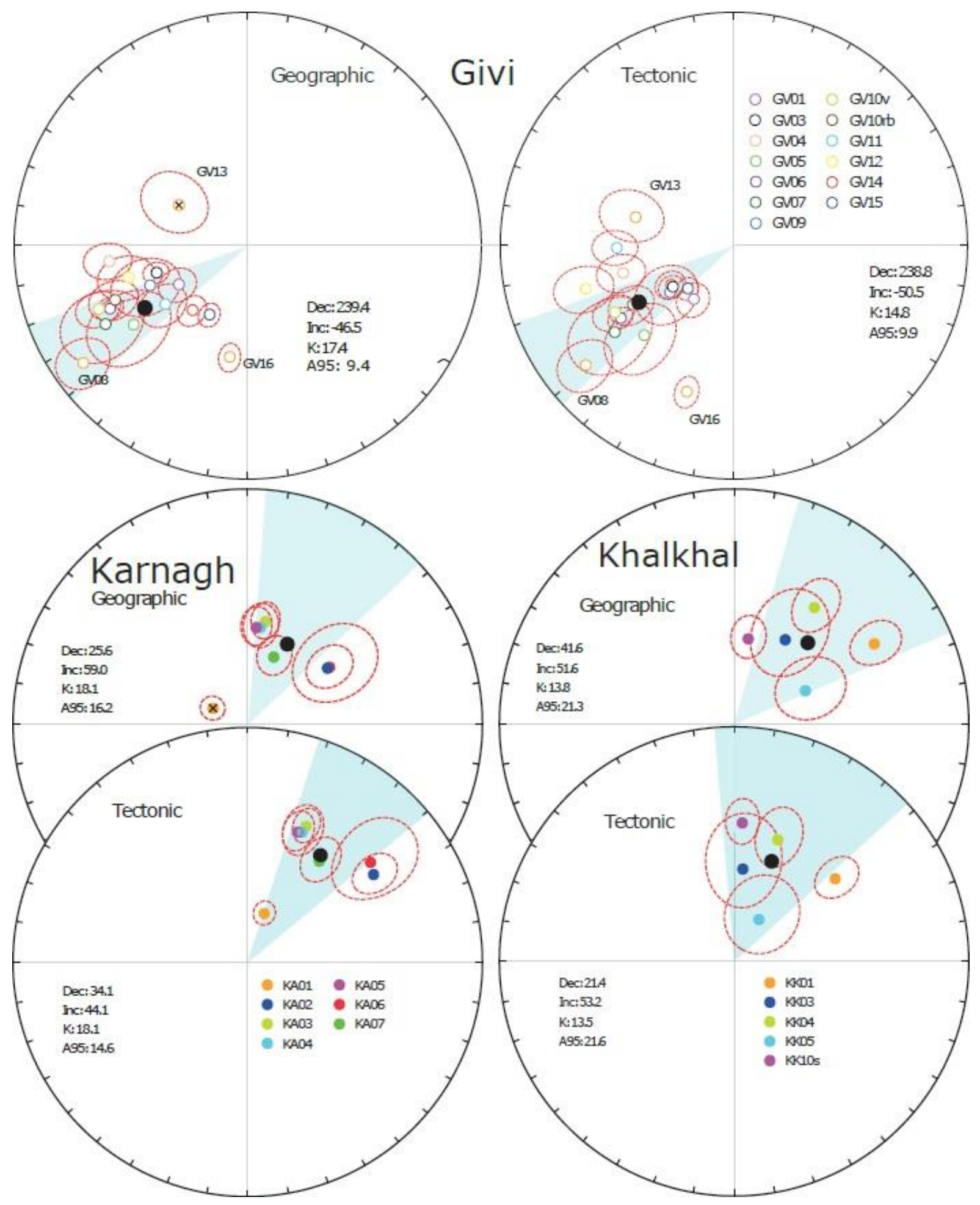

Fig. 4: Site averages and their $\alpha 95$ confidence ellipses together with the locality averages (large black circles) and declination parachutes $\left(\Delta D_{x}\right)$ for the Givi (GV), Karnagh (KA) and Khalkhal (KK) series. 

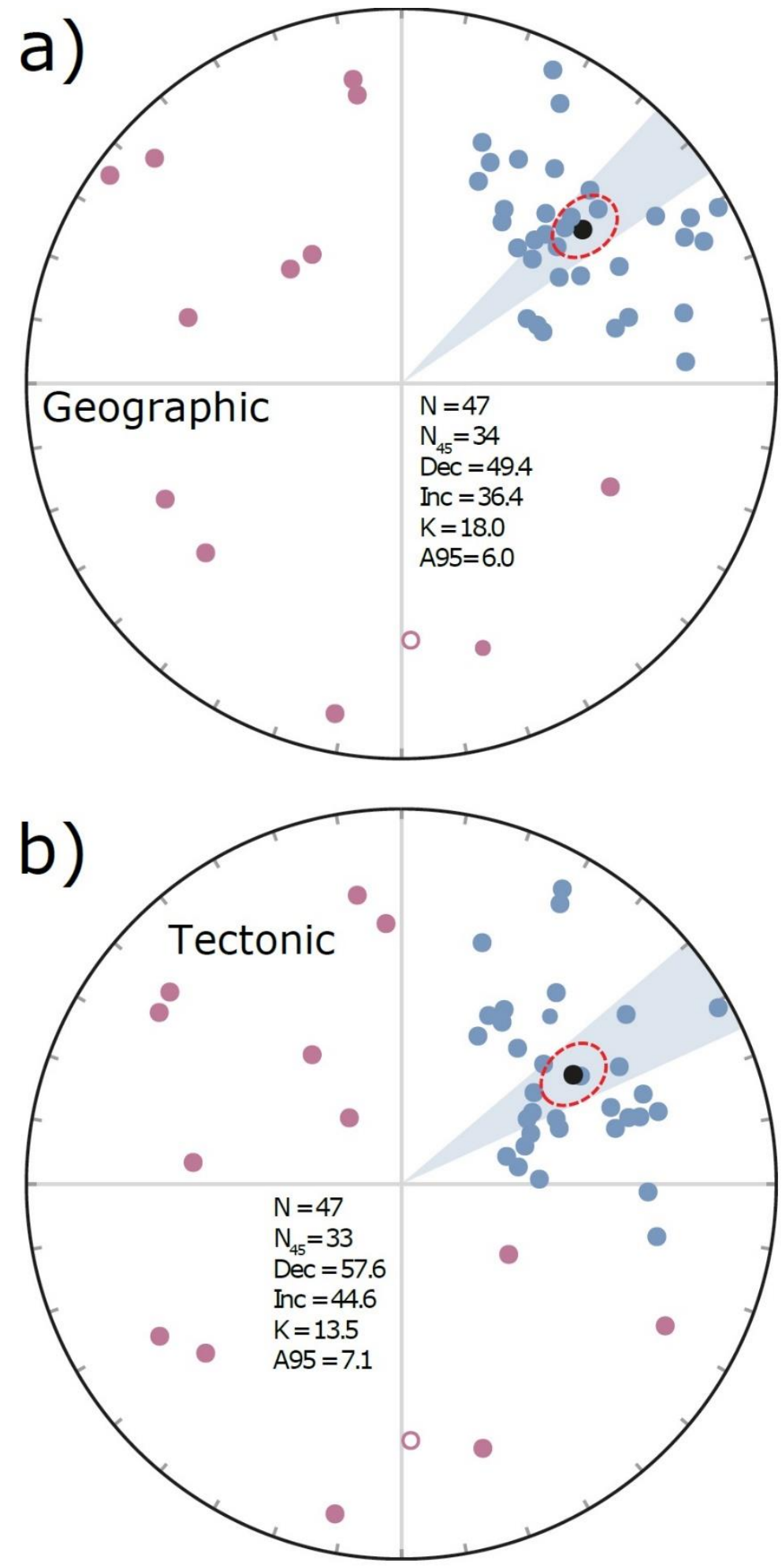

Fig. 5: Individual ChRM directions accepted (blue) and rejected by the $45^{\circ}$ cut-off (red) and their mean (black) including the A95 ellipse and declination parachute $\left(\Delta D_{x}\right)$ from the NL series in a) Geographic and b) Tectonic coordinates. 

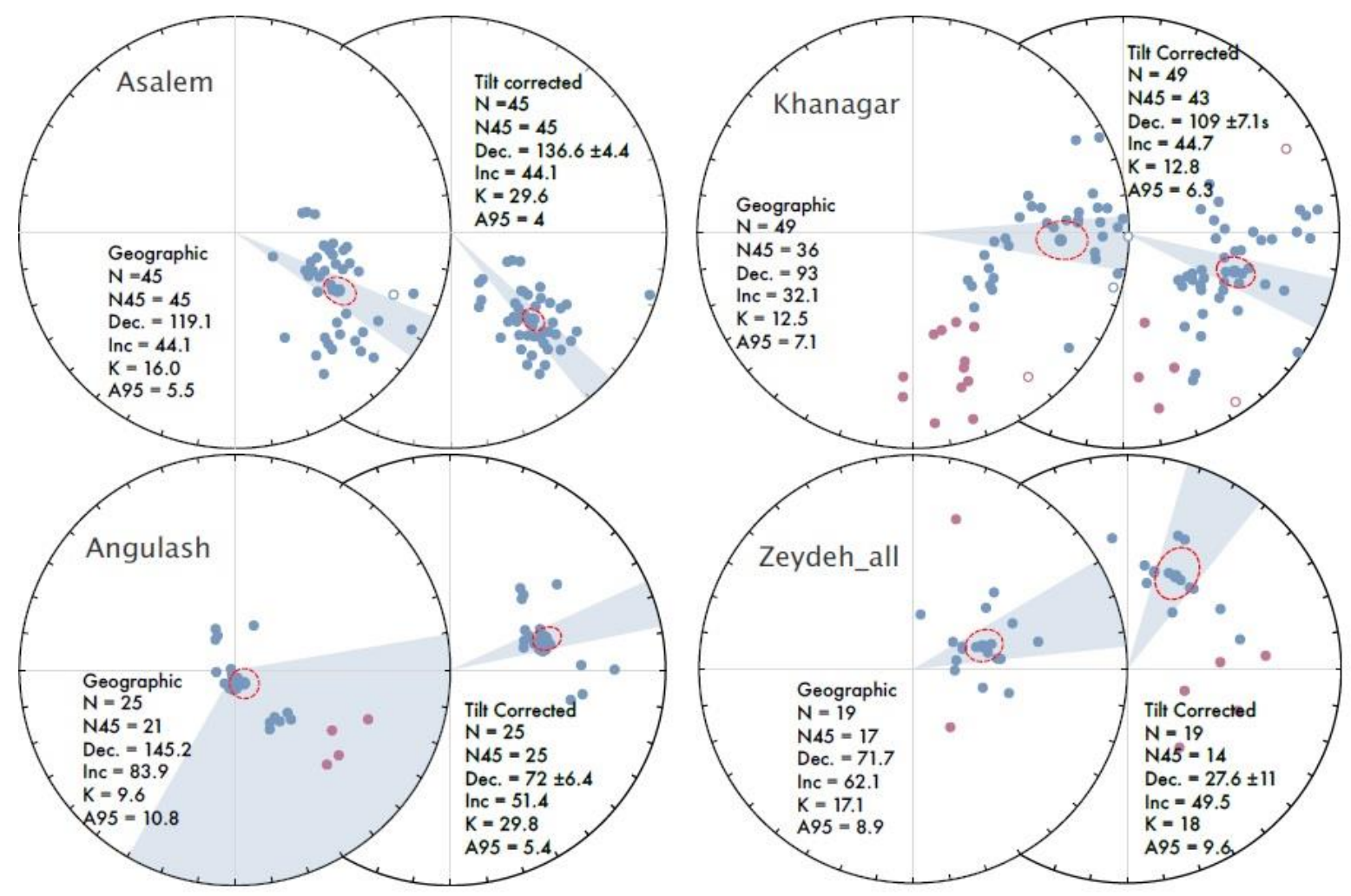

Fig. 6: Individual ChRM directions (blue is accepted, red is rejected) and their means including the A95 ellipse and declination parachute $\left(\Delta D_{x}\right)$ from the pre-Eocene series (Tseries) in Geographic and Tilt-corrected coordinates. 

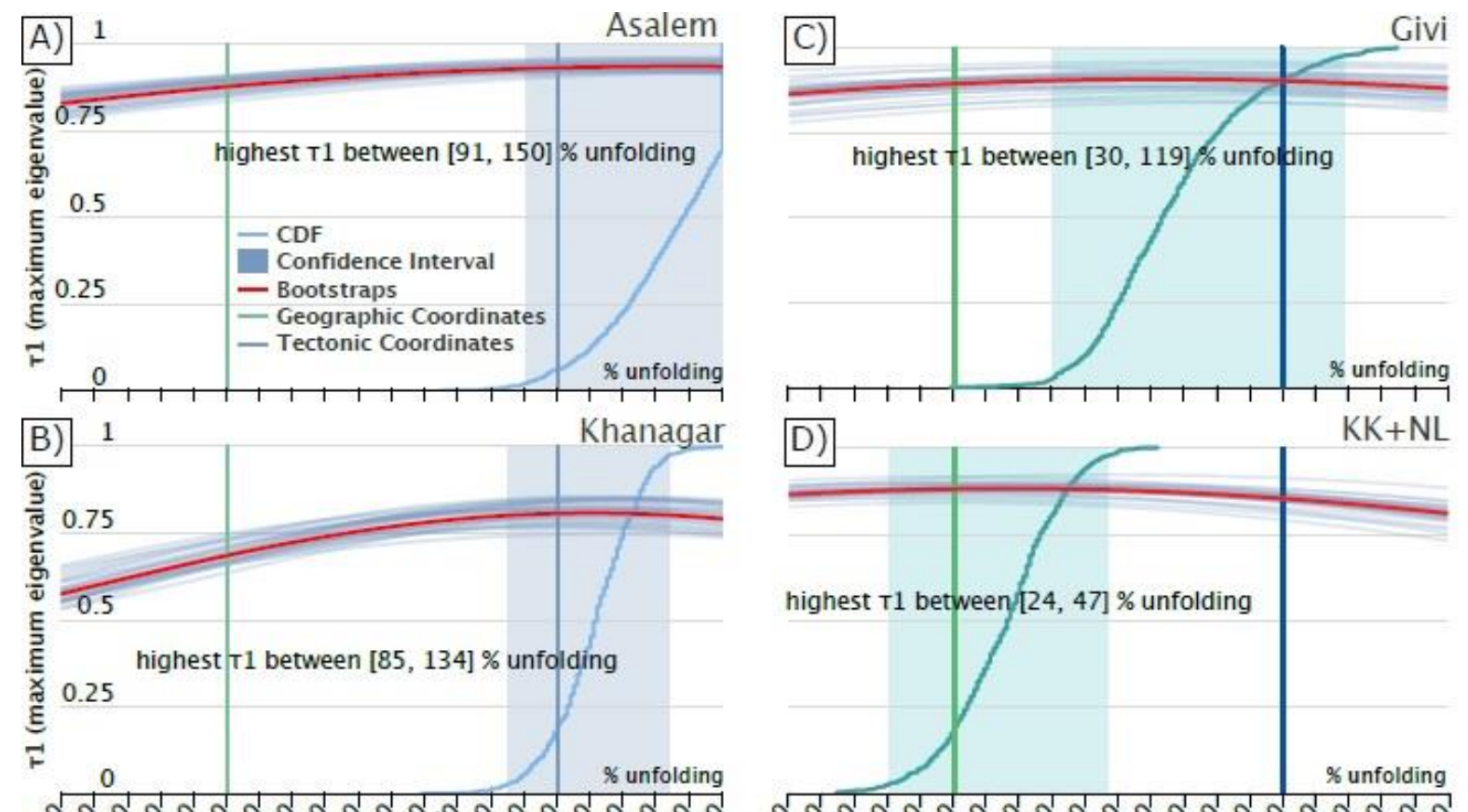

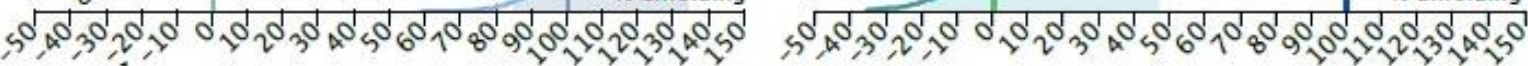
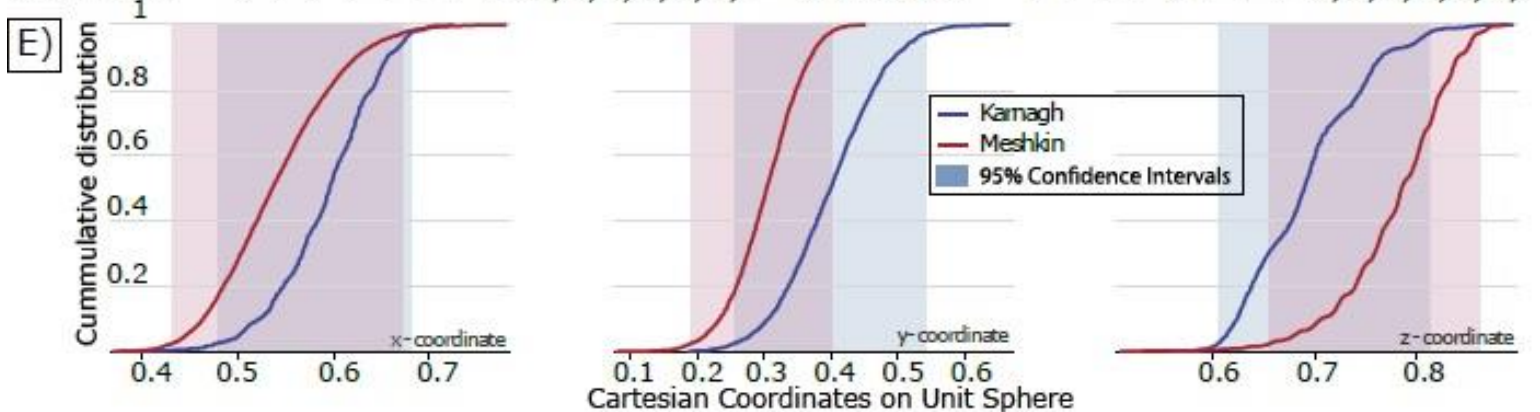

Fig. 7: Fold tests and common true mean direction (CTMD) tests (see Koymans et al., 2016; 2020, and references therein). The pre-Eocene Asalem (A) and Khanagar (B) localities show convincing positive fold tests, indicating the pre-folding nature of the magnetization. Givi (GV) shows a marginally positive fold test. The fold test from Khalkhal and Nummulitic limestone (D) is negative. Karnagh and Meshkin share a common true mean direction (E). 


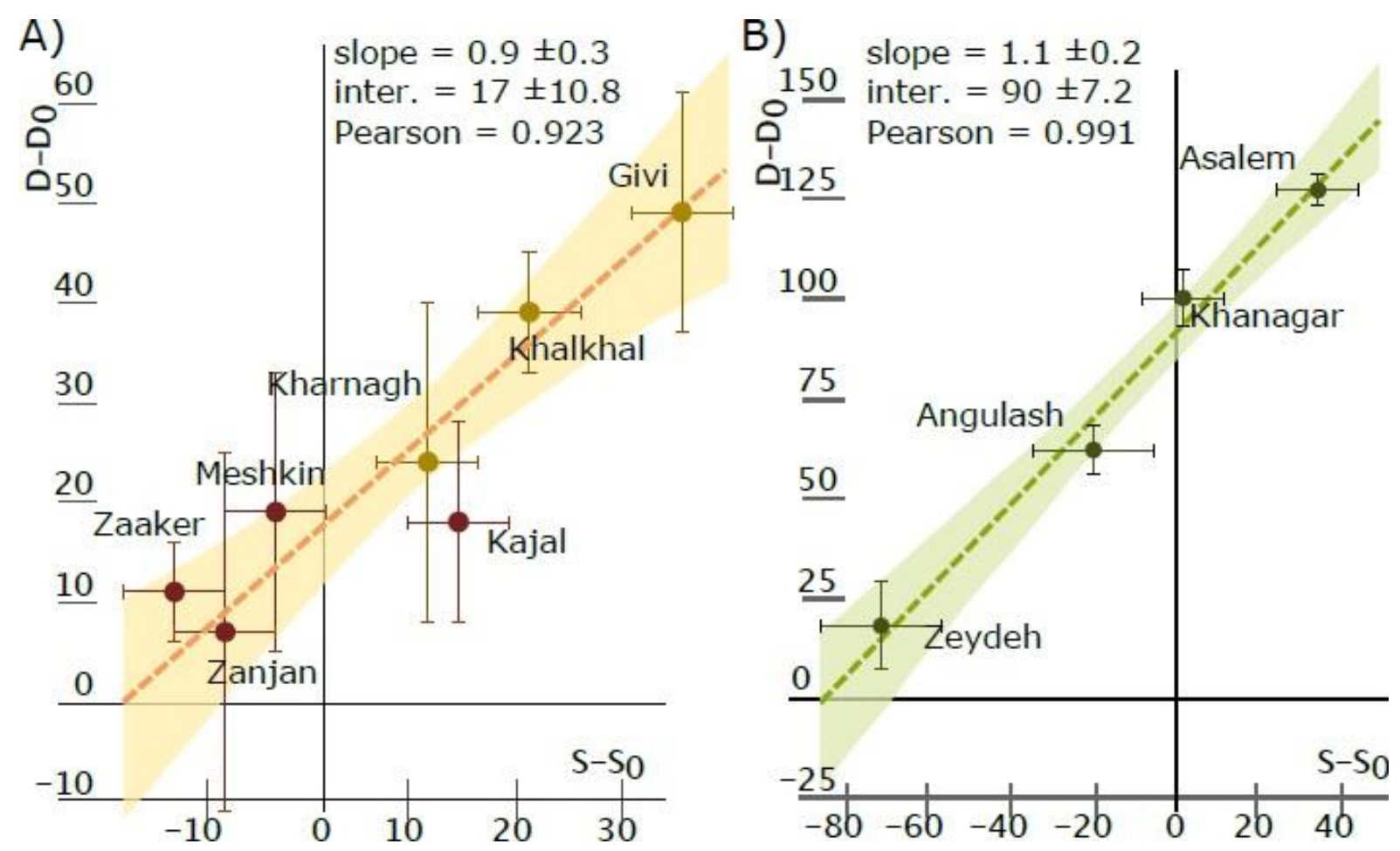

Fig. 8: A) Bootstrapped orocline tests (Pastor-Galán et al., 2017) for the Givi, Khalkhal, Karnagh series (in pale green) and localities of van der Boon et al. (2018) (in red). B) Bootstrapped orocline test for the T-series. Both orocline tests are positive with a high Pearson correlation coefficient. 


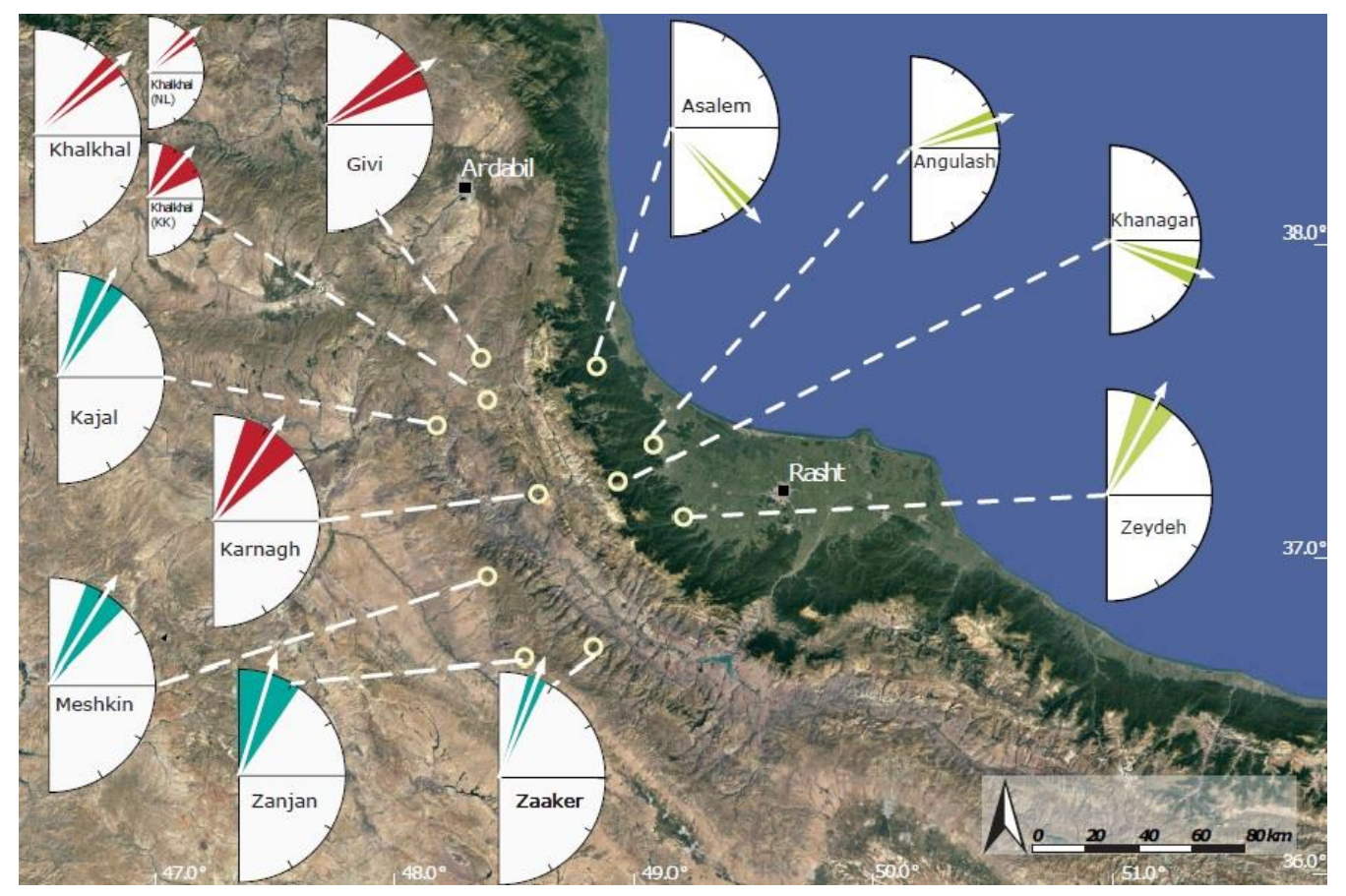

Fig. 9: Satellite photograph showing the Talesh orogenic trend and the average declinations with confidence parachutes $\left(\Delta D_{x}\right)$ from the studied localities in green (Cretaceous) and red (Eocene). We also included localities from van der Boon et al. (2018) (turquoise blue, Zaaker, Zanjan, Meshkin and Kajal). Reference declination is approximately constant around $10^{\circ}$ from the Cretaceous to the Oligocene (Torsvik et al., 2012). 

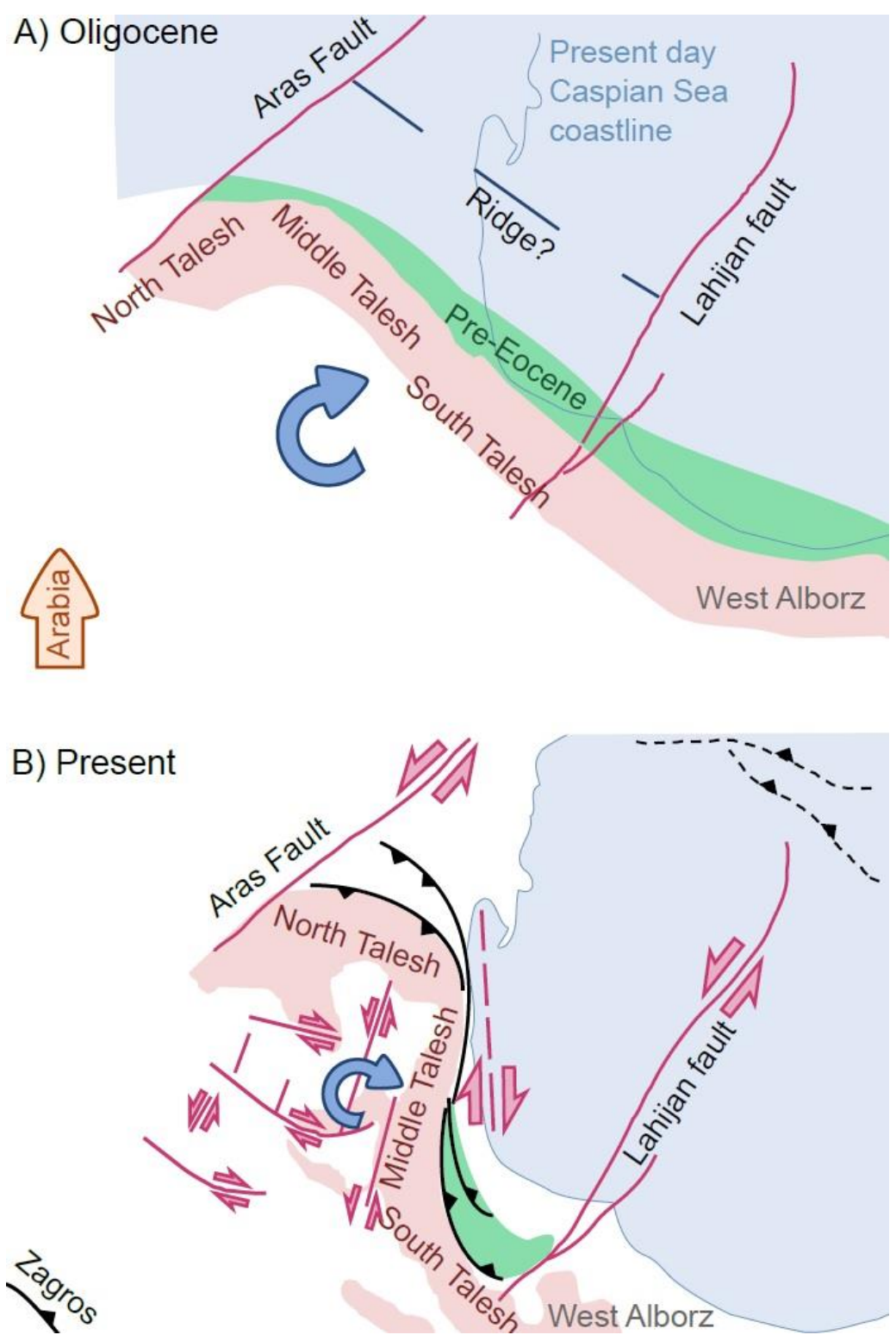

Fig. 10: Cartoon showing a hypothes is for the formation of the Talesh coupled oroclines. A) During or after the Eocene, the indenting Arabian plate forced the clockwise rotation of the Eocene volcanic belt together with the pre-Eocene sedimentary sequence. The Aras-Lahijan fault system possibly represents a transform-ridge system, inherited from the Late Jurassic rifting of the Caspian-Black seas back arc (e.g. Abdullayev et al., 2017). B) Ongoing convergence and compression around the rigid South Caspian Basin caused the additional rotation of the Middle Talesh, together with strike-slip tectonics along the Caspian Sea margin (e.g. Kadirov et al., 2008) and the rejuvenation of the Aras-Lahijan fault system. Fault arrays within the Aras-Lahijan system were adopted from Faridi et al. (2017). 